\title{
Perception Of Television Advertising From China's Young Generation
}

Lijie Li, ESC Rennes School of Business, France

Laurent Scaringella, ESC Rennes School of Business, France

\begin{abstract}
This paper aims to examine the elements employed in television advertising, which affect consumer attitudes toward advertised products and brands. 384 young Chinese responded to a survey questionnaire. This paper finds that celebrity endorsement positively affects creativity in television advertising. The credibility of television advertisement positively affects the recall of products and brands. Celebrities in television advertising or people who have professional knowledge as endorsers decrease the credibility of television advertisements contrary to the results of previous research. Creativity in television advertising has a negative effect on the recalls of products and brands. This paper offers insight about the young generation's perception of television advertising in China. It provides a debated perspective that creativity in television advertising negatively affects product and brand recalls.
\end{abstract}

Keywords: Television Advertising; Celebrity Endorsement; Credibility; Product and Brand Recalls

\section{INTRODUCTION}

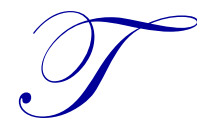

his paper aims to examine television advertising and the elements employed which affect consumer attitudes of Chinese young generation toward advertised products and brands. The initial assumptions of the paper is considering advertising as a process that transforms values and the meaning of existing ideologies into the world of consumer goods (Callow \& Schiffman, 2004; Fay, 2004; Lears, 1994; Marchand, 1985; Williamson, 1978). However, most consumers avoid television advertisements. Television advertising can lose its effectiveness because overwhelming advertisements can have a negative effect on consumers' emotions (Mediamark Research and Intelligence, 2008; Papper et al., 2005). However, Heath and Stipp (2011) argue that television advertising is still an effective marketing tool. Rubinson (2009) confirms that even if consumers pay less attention to television advertisements, they are still subconsciously influenced by advertisements.

The focus of our paper is to investigate which elements (i.e., credibility, creativity, or celebrity endorsement) make television advertising more effective for China's young generation.

The main research objective of this article is to answer the following research question: How does television advertising affect consumers?

Our paper is original in the field of television advertising with a particular focus on China's young generation. Few studies discuss the effect of different elements in television advertising, and research about the young Chinese generation's perceptions and attitudes about television advertisement is limited. We believe that this gap is worth researching. The contribution to knowledge of the article is the study of advertising credibility, celebrity endorsement, creativity, the recall of products and brands, and the intentions to purchase.

\section{BACKGROUND}

Compared to Western countries, China has a specialized background for television advertising. Although Chinese advertising is controlled by governmental regulations, advertising has become more international in recent years (Weber, 2000; Wang, 2008). Advertisements must adhere to China's advertising law, political ideology, and 
cultural perceptions. Even successful international companies cannot freely translate and express their ideas about products in their advertisements.

In the 21st century, the construction of society is gradually changing from communism into consumerism. China's new generation receives more information from foreign countries. Their perception is becoming less connected with communism. Surveys indicate that consumerism is replacing or has replaced the dominant communist ideology of previous generations (Barme, 1999; Croll, 2006; Davis, 2000).

With the change in perceptions of the young generation, advertising in China has become less political. However, the restrictions still exist and are not easy to eliminate because of their long historical, cultural, and political influence. Chinese advertising regulation is one of the most significant obstacles for marketers and advertisers. However, although Chinese advertising is not as open as advertising in Western countries, Chinese consumers - particularly the young generation-are accepting new ideologies instead of adhering to the conventional ideologies. They enjoy quality products, comfortable lifestyles, and luxuries brought by Western companies and also hold a strong sense of national pride (Hughes, 2006; Xu, 2008).

\section{THEORETICAL, CONCEPTUAL FRAMEWORK}

Television advertising was believed to be one of the most effective marketing tools because it can reach consumers by transmitting information vividly. Nevertheless, the effectiveness of television advertising is debated. Improving the effectiveness of television advertising is considered a critical task. In this paper, we will discuss three elements employed in advertising: credibility, creativity, and celebrity endorsement.

\section{Credibility}

Is television advertising still an effective tool? Heath and Stipp (2011) indicate that the effect of television has been a subject of continuous debate for the last 50 years. Does television affect consumers? Previous studies (Mediamark Research andIntelligence, 2008; Papper et al., 2005) suggest that television advertising is losing or has lost effectiveness because the attitude of consumers toward television advertising is becoming more negative. Because advertisements are too numerous and long, most viewers pay less attention to them. They prefer to perform other activities when they watch television or only listen to the advertisements passively. However, Heath and Stipp (2011) conclude that television advertising is still a useful marketing tool for advertisers to build a strong brand and persuade consumers. Although Rubinson (2009) initially assumed that television advertising has lost effectiveness, the results of his study indicate that television advertising has an impact on consumers because it can generate brand awareness.

Most television advertisements are not closely watched, and consumers prefer to perform other activities when they watch them. Is television advertising that consumers neglect or pay little attention to still effective compared to advertising that they watch closely? Bellman et al. (2010) demonstrate that the consumers' behavior in avoiding advertisements can be classified as first, physical avoidance, which means the absence of the audience; second, mechanical avoidance, in which the audience switches channels; and third, cognitive avoidance, which means that the audience is "present but not viewing." With the invention of digital video recorders (DVRs), viewers can easily avoid advertisements by zipping (fast-forwarding) or zapping (channel switching) to skip them.

However, advertisements to which consumers pay little or partial attention still have residual effects on spontaneous recall, although at a much more lower rate than advertisements that receive consumers full attention (i.e., a 54\% decrease in spontaneous recall rates). Previous studies (Zufryden et al., 1993; Greene, 1988) indicate that switching channels and fast-forwarding require viewers to pay attention to the screen, which is called "providential attention back to set." Viewers can remember zipped and zapped advertisements, and the advertising has a chance to generate product purchases. In addition, the study of Bellman et al. (2010) suggests that zipped and zapped (partial-exposure) advertisements can be effective reminders (Gilmore \& Secunda, 1993).

High attention to commercials is hard to obtain because current viewers are not attracted by television advertisements. They have less patience for sitting in front of television and appreciating an advertisement than in 
the past. Can low attention to advertisements still lead to effective advertising? The answer is yes. According to Bornstein (1989), less attention brings better communication. Nordheilm (2002) confirms that advertisements "wear out" and a high frequency of advertisements are repugnant to viewers. In contrast, less attention to advertisements increases positive emotional influence and makes advertisements more acceptable. Bellman et al. (2010) conclude that zapped advertisements are no less effective than full-attention ones, even when consumers are skipping advertisements with DVRs. Therefore, television advertisement is still a strong marketing tool.

According to the studies of Plummer (2006), Bornstein (1989), and Nordheilm (2002), the phenomenon that viewers tend to avoid television advertisements does indeed exist. However, television advertising is effective as long as viewers pay some attention to it. Two issues affect the attraction of consumers' attention: the credibility of television advertising and the attractiveness of the television advertisement. Therefore, it is critical to understand what elements in television advertisements are critical and how they can generate positive attitudes and purchase intentions in consumers.

\section{Creativity}

Creativity is a vital component of advertising because it can attract consumers' attention and helps consumers to recall the commercials, advertised products, and brand names. Creativity is considered one of the most effective elements in advertising to break through media clutter, reach the consumers' minds, and build an impressive advertising campaign. Therefore, marketers tend to make advertisements more novel and creative (Ang et al., 2007). Jones (1990) indicates that creativity in advertising is used to diffuse information into consumers' minds. Creative advertising provides consumers with more information and knowledge, thus changing their attitudes and persuading them to repeatedly buy a brand.

Creative commercials will stay in consumers' memory for a longer time than typical advertisements. Even one week after watching the creative advertisement, consumers can recall it much easier than a normal commercial (Till \& Baack, 2005). Kover et al. (1995) also demonstrate that creativity in advertisements can draw upon consumers' emotions, which is a critical element to catching consumers' attention. Heath and Stipp (2011) conclude that at the end of the 1990s, television advertising was still an effective method to communicate with consumers, persuading them and influencing their attitude toward products. Emotive elements that successfully influence consumers, such as creativity, are an important factor in increasing consumers' attention and improving the effectiveness of advertising.

Creativity in advertising has been studied extensively. Ang and Low (2000), Kover et al. (1995), and Stone et al. (2000) demonstrate that creative advertising improves attitudes toward brands and increases purchase intentions and product likability. According to "novelty-attention-recall" theory (Ang et al., 2007) and evidence from previous studies (Ang et al., 2007; Ray, 1982; Haberland \& Dacin, 1992), creative advertising is more novel and unexpected. Creative advertisements can augment the processing of "attention-recall," which requires a deeper thought process in viewers' minds (e.g., Anderson, 1983; Srull, 1981; Keller, 1993). Moreover, creative advertisements are more meaningful (Ang \& Low, 2000; Ang et al., 2007). Novel and meaningful commercials are more likely to facilitate the information process in viewers' minds than novel but non-meaningful advertisements (Bransford \& Johnson, 1972; Ang et al., 2007), which leads to greater recall (Ang et al., 2007; Lee \& Mason, 1999; Heckler \& Childers, 1992).

Furthermore, more creative advertisements can generate emotional content in consumers' minds (Plummer, 2006). Plummer (2006) has conducted two research studies. The first study demonstrates the important role of consumer emotion, which builds a strong brand. He summarizes two constructs - cognitive power and emotive power - that represent rational information (i.e., message) and emotional content (i.e., creativity) in advertising. The second study tests the effects of emotional and rational content on shifts in brand favorability. The results indicate a significant linear relationship between emotional content and shift in brand favorability but no significant relationship between rational content and shift in favorability. This study confirms that television advertising is effective in persuading consumers and that the rational content or information cannot change consumers' attitudes toward a brand. The emotional content of advertisements, which is represented as creativity, can encourage a stronger brand image. 
Plummer's (2006) findings imply that creative advertisements can lead to positive attitudes toward brands and improve purchase intentions. Creative advertisements are more effective in enhancing unaided brand recall and advertisement recall and unaided recall persists for a longer time. According to Till and Baack (2005), the element of creativity in television advertising can encourage consumers to recall information and generate emotional reactions.

\section{Celebrity Endorsement}

"Celebrity endorsement advertising has been recognized as 'a ubiquitous feature of modern marketing"” (McCracken, 1989). Statistics indicate that the employment of celebrities in advertising in the USA increased from approximately $15 \%$ to $25 \%$ from 1979 to 1997 . In Japan, celebrities appear in nearly $70 \%$ of advertisements (Kilburn, 1998). Hsu and McDonald (2002) cite previous research demonstrating that celebrity endorsers affect the audience's attention, recall, evaluations, and purchase intentions.

According to McCracken (1989), celebrity endorsement affects consumers in a process that can by represented by a three-stage meaning transfer model: the celebrity transfers meaning to his public image with his credibility and expertise; then, he transfers the meaning to the brand being endorsed; and finally, the meaning is transferred to consumers. Celebrities facilitate brands persuading consumers to use their products (e.g., Kamins et al., 1989; Ohanian, 1991). Celebrity and brand credibility are combined to improve the consumer-based brand equity, which is defined as the combination of brand loyalty, brand awareness, perceived quality of a brand, and meaningful memories linked to a brand (Yoo \& Donthu, 2001).

Traditionally, as Tom et al. (1992) suggest, certain celebrities have different social powers, such as expert, referent, legitimate, coercive, and reward powers, which are useful for affecting consumers' perceptions. For instance, according to Caughey $(1984,1985,1994)$, young people admire idols and consider or refine themselves to be similar to their idols. They imitate idols' physical appearances, abilities, and attitudes. Some consumers, particularly young consumers, perceive that they have a relationship with celebrities. This type of celebrity worship makes them feel that the celebrities are close to them. One fan of Elvis Presley said "I can feel him in my heart. I can see him in my dreams. I can see him on my wall in my posters, that's the stuff that's the real Elvis" (Fraser \& Brown, 2002). Young consumers confirm that they prefer to use products endorsed by celebrities, such as entertainers and famous athletes (Lafferty \& Goldsmith, 1999). Celebrities affect the brand selection and brand switching of young consumers (Martin \& Bush, 2000).

Normally, celebrities chosen to promote products should have four characteristics: attractiveness, expertise, trustworthiness, and a match between the product and endorser, which determines communication effectiveness (Kahle \& Homer, 1985; Kalra \& Goodstein, 1998; Kamins \& Gupta, 1994; Misra \& Beatty, 1990; Sengupta et al., 1997; Till \& Busler, 1998).

Marketers always choose endorsers who are attractive, credible, and knowledgeable. At the same time, celebrity endorsers should be matched with the expected brand image. Physically attractive celebrities can enhance the image of brands that they endorse and encourage consumers' intention to purchase the brand and products (Hakimiet et al., 2011). McGuire's (1985) source attractiveness model describes this phenomenon. The model concludes that physical attractiveness is an important cue in an individual's initial judgment of another individual (Baker \& Churchill, 1977; Chaiken, 1979; Joseph, 1982; Kahle \& Homer, 1985; Mills \& Aronson, 1965; Widgery \& Ruch, 1981). Consumers who are not fans of celebrities expect to see physically attractive people in television commercials. Therefore, advertisers prefer to select more attractive spokespersons. Furthermore, according to Ohanian (1990), a celebrity who is credible can persuade consumers to believe what he presents about the brand in the advertisement. Expertise in advertisement can make consumers more willing to buy the product being advertised. Consumers prefer congruity between the product advertised and endorser, such as an athletic brand endorsed by a famous athlete (Chien et al., 2011). The meaning transferred by a related endorser is greater than meaning transferred by an unrelated endorser.

Another strategy is the multi-endorsement. The marketers and advertisers will choose one celebrity or multiple celebrity endorsers to advertise a product based on its characteristics. The multiple celebrity strategy is 
employed because "a brand has a wide range of consumers and sometimes this strategy is needed to cover the whole target audience. But each chosen celebrity's value should reflect core brand values." Each celebrity possesses compatible meanings that are sought for brand so as not to confuse consumers and diminish brand image (Erdogan \& Baker, 2000).

The research indicates that stars and famous athletes influence American adolescents' consumption intentions and behavior (Martin \& Bush, 2000). Sports celebrities can generate positive word-of-mouth recommendations for a brand, which improves purchase intention and follow-through among Australian young people (Buksa \& Mitsis, 2011; Dix et al., 2010). In South Africa, a positive relationship exists between celebrity endorsement and purchase intention (Makgosa, 2010). In China, 40\% of product advertisements directed toward youth feature at least one celebrity (Chan, 2008), which is considered an effective strategy for advertisers. The Chinese market has a different culture than other countries due to the high value of personal relations or guanxi in China (Gu et al., 2008). The young generation in China now has significant consumer power, is more fashion and brand conscious, and can more easily access and accept the ideas of Western countries (Arora, 2005; Stanat, 2006) through the Internet using new technologies.

\section{Television Advertising Related to Recall and Purchase Intentions}

Television advertising can make consumers recall and encourage them to purchase advertised products as it is illustrated above because advertising contains elements of credibility, celebrity endorsement, and creativity that change consumers' attitudes and behavior.

Companies also invest large sums of money annually to create television, radio, and magazine advertisements that reach and persuade more consumers to influence their behavior. According to previous studies (Ramalingam et al., 2006) in different countries, television advertising is the most effective means of persuading consumers and affecting their purchasing processes because television advertising has three critical advantages. First, television advertising gradually penetrates and influences consumers' perceptions. Second, television commercials can reach a wide range of audiences. Third, sound and images used in television advertising generate a strong impression. According to Rice and Atkin (2001), television advertising affects viewers because companies that spend a large amount of money on advertising require results and proportional effects are realized when people spend a certain number of hours watching television. Mohammad and Seyyed (2011) demonstrate that television advertisement has a positive effect on viewers' attention, interest, desire to purchase products, purchasing behavior, and consumer satisfaction.

Although previous research offers evidence for analyzing the effectiveness of television advertising, the effect of each element in an advertisement is not specified in previous studies. Moreover, few studies have focused on the Chinese market, which has been growing rapidly in recent decades. Economic development, the policy of opening to the outside world, and the increased consumption in China make the Chinese market attractive for most international enterprises, which recognize the potential for profit. However, China is a huge market with significant challenges, including its large population and unique consumer customs. This study will provide a general review of the perception of China's young generation toward television advertising and offer evidence of the young generation's propensity to consume and consumption behavior.

\section{RESEARCH MODEL}

Nine hypotheses arise from this review. Celebrity endorsement is considered an important element in modern marketing, and its use has become more popular globally. According to Hsu and McDonald (2002), celebrity and expertise can affect audiences' attention to advertising, recall, evaluation, and purchasing attention to the product and brand. McCracken's (1989) theory supports the process of value transfer from the celebrity to consumers via the brand, which indicates that endorsers can successfully persuade consumers to use the endorsed products.

Psychologically, celebrity endorsements of pop stars, athletes, or experts can make consumers imitate endorsers, believe what they claim, and use the advertised products because of the endorser's performance 
(Caughey, 1984, 1985, 1994). Based on the previous studies, we believe that a positive relationship exists between celebrity endorsement and the credibility of television advertisements. Therefore, our hypothesis is summarized as:

H1: CE (celebrity endorsement) has a positive effect on CR (credibility).

Another element that makes television advertising more effective is creativity. A creative advertisement can persuade consumers and encourage recall. Johns (1990) also presents evidence that advertisers employ creativity in advertising to diffuse information into consumers' minds. Based on these studies, we hypothesize that a relationship exists between a celebrity endorsement and the creativity of advertisements such that consumers perceive that television advertisements with a celebrity endorsement are more creative than advertisements without celebrities. The hypothesis can be illustrated as:

H2: CE has a positive effect on CA (creativity in advertising).

Two features indicate whether television advertisements are effective: product and brand recall and purchase intention. How can an advertisement make viewers recall the brand and product and trigger their purchase intentions? The first factor to analyze is the credibility of television advertising. People have overwhelmingly lost their patience with television advertising. Researchers (Mediamark Research and Intelligence, 2008; Papper et al., 2005) indicate that television advertising is no longer effective because people are tired of it and do not believe what the advertisements claim. Consequently, viewers prefer to avoid commercials. Less attention to advertisement is normal for all audiences. However, Heath and Stipp (2011) argue that television advertising is still useful and credible, which allows it to build brands and persuade consumers.

To confirm the effectiveness of television advertising, Rubinson (2009) finds that although people pay less attention to television advertising and tend to avoid it, television advertising still has a definite impact on consumers. Furthermore, Rubinson (2009) demonstrates that television advertising can generate brand awareness. Based on the studies described above, our hypothesis can be illustrated as:

H3: $\quad$ CR has a positive effect on PBR (products and brands recall).

Although television advertisements attract less attention, Bornstein's (1989) psychology experiment demonstrates that communication increases with low levels of attention. Moreover, Nordheilm (2002) claims that high attention to advertisement "wears out" advertisements, which could have a negative effect on viewers. People are influenced by television advertising regardless of their level of attention.

According to Ramalingam et al. (2006), people will be influenced by television advertising because advertising has three functions. First, it can reach a wide range of audiences. Second, sound and moving images make the commercials memorable. Third, television advertising can affect consumers' perception gradually without consumers' awareness. Furthermore, Mohammad and Seyyed (2011) demonstrate that a positive correlation exists between television advertising and viewers' attention, interest, and purchasing desire. A positive relationship also exists between television advertising and consumers' purchasing action and satisfaction. People believe what television advertisements claim.

According to Woltman Elpers, Wedel, and Pieters (2003), entertainment in ad is an effective way to capture consumers' initial attention and interest. Indeed, entertaining and creative commercials do really work on increasing brand purchase intention by reducing the consumer's resistance to persuasion (Yang \& Smith, 2009). It seems that increasing an advertisement's attractiveness and persuasiveness are effective. However, the most entertaining or funniest ads do not mean that they are the most effective ones (Teixeira \& Stipp, 2013). These ads regarded as the funniest and the most entertaining do not necessarily make the ads effective. Therefore, it is important to consider the appropriate amount of entertainment in television commercials according to Teixeira and Stipp (2013). Based on previous studies, we believe a positive relationship exists between the credibility of advertisements and consumers' purchase intentions, which we present as:

H4: CR has a positive effect on PI (purchase intention). 
Ang et al. (2007) have developed the 'novelty-attention-recall' theory. Ray (1982) and Haberland and Dacin (1992) argue that creative advertisement adds novelty to trigger the 'novelty-attention-recall' process. According to Ang and Low (2000) and Ang et al. (2007), creative advertisements are more meaningful than novel non-meaningful advertisements because they accelerate the process and lead to greater recall (Ang et al., 2007; Lee \& Mason, 1999; Heckler \& Childers, 1992). Till and Baack (2005) confirm that creativity is a critical element in television advertising because creative advertisements will stay in people's minds longer; people can recall these commercials much easier than the 'normal' commercials even after one week.

H5: CA has a positive effect on PBR.

In addition to product and brand recall, purchase intention is another value for evaluating the effectiveness of television advertising. Previous studies demonstrate that creative advertising can generate positive attitudes toward brands and interest in purchasing (Ang \& Low, 2000; Kover et al., 1995; Stone et al., 2000). In addition, Johns (1990) finds that creative advertising is more effective at diffusing information in consumers' minds. Persuasive advertising transfers more information and knowledge to viewers that can encourage them to change their attitudes and perceptions, which affects their purchase intentions and behavior.

In Asian countries, advertisers might have lots of constrain when they try to send their information in the ads because of the religious and culture issues and restrictions (Fam et al., 2004). 'Entertaining' ads, such as humorous and interesting styles will be the safest way to communicate with the audiences. Culture values have a significant important effect on consumer consumption and consumer behavior (Fam et al., 2013). We hypothesize that:

H6: CA has a positive effect on PI.

The use of celebrities in television commercials will enhance brand image. Consequently, consumers can recall brands and products after seeing commercials (Hakimi et al., 2011). Previous studies have found evidence to support the effect of celebrity endorsers on the audience's attention, recall, evaluations, and purchase intentions (McDonald, 2002). The endorsers could be admired cultural idols or physically attractive people. Consumers, particularly those in the younger generation, will imitate their idols. The employment of cultural idols is a strategy to shorten the distance between celebrities and their followers to make consumers feel similar to their idols (Caughey, 1984, 1985, 1994). Idols who are credible as spokespersons lead to a strong consumer recall of the product and brand endorsed (Yoo \& Donthu, 2001). We hypothesize that a relationship exists between celebrity endorsement and product brand recall, illustrated as:

H7: CE has a positive effect on PBR.

At the same time, previous literature has demonstrated that celebrity endorsement in television advertising can persuade consumers to use advertised products because the well-known celebrity who endorsed the brand endorsed can quickly capture consumers' attention (e.g., Kamins et al., 1989; Ohanian, 1991). Thanks to the celebrity's power, such as idol effect, expertise knowledge, and appearance attractiveness, consumers will be encouraged to purchase the brand and product. Young consumers confirm that they prefer to use products endorsed by celebrities, such as entertainers and famous athletes (Lafferty \& Goldsmith, 1999).

Aziz et al. (2013) argue that there is a positive relationship between celebrity credibility, consumer's feelings to advertisement, to the product and their buying intention. Advertisement using credible celebrities will help achieving further positive effect toward the ads than the advertisements employing less credible celebrities. Credible celebrities make not only the brand trustworthy but also differentiate the brand from the others. Hence, we assume that celebrity endorsement positively affects purchase intention and hypothesize that:

H8: CE has a positive effect on PI.

Finally, we assume that television advertising can encourage consumers to recall the advertised brand and product. However, does recall of the advertised product and brand arouse consumers' purchase intentions? Several 
previous studies have analyzed the relationship between such elements as creativity and celebrity in advertising. However, few studies have examined the direct relationship between product and brand recall and purchase intention. Will consumers buy the advertised product when they shop? When can they recall the advertised brand and product? Does this recall affect consumers' decision to purchase one product instead of another? In response to these questions, the ninth hypothesis is defined as:

H9: $\quad$ PBR has a positive effect on PI.

\section{METHODS}

We used structural equation modeling with AMOS 18. We used SEM in a strictly confirmatory approach (Joreskog, 1993) for hypothesis testing only. The theory led us to measure multiple variables and develop causal processes in the form of regressions, equations, and models (Bentler, 1988). SEM is used to explain the relationships among multiple variables through the structure of interrelationships between constructs through a structural model or a series of multiple independent regressions.

Because our five theoretical constructs (CE, CR, CA, PBR, and PI) cannot be observed and measured directly, we considered them as latent factors. We only used multi-item reflective scales scored on five-, six-, seven-, eight-point Likert scales.

The CE (14 items) construct is based on Ohanian's (1990) study of "expertise, trustworthiness, and attractiveness of celebrity endorsers." The literature on persuasive communications has demonstrated that three dimensions are effective in attitude change studies. Each dimension of source credibility is composed of five different semantic items scored on 7-point Likert scales.

CR (nine items) is a construct that was developed by Obermiller and Spangenberg (1998). Skepticism toward advertising is defined as the general tendency toward disbelief in advertising claims. All items for the measurement of advertisement credibility were operationalized using a five-place response format ranging from strongly agree $=1$ to strongly disagree $=5$.

The CA (five items) construct is part of a multidimensional scale developed by Lastovicka (1983) that reflects an overall positive evaluation or feeling, as opposed to irritation, with respect to a commercial's execution. Structured questions were administered using a Likert-type format with a scale ranging from 1 (strongly disagree) to 6 (strongly agree).

The PBR (25 items) construct was developed by Wells (1964). Because emotional appeal is an important dimension of advertising recall, two scales were developed to estimate consumers' emotional reactions to advertisements. The Emotional Quotient (EQ) scale measures the global emotional reaction toward advertisements, and the Reaction Profile assesses three specific emotional reactions toward advertisements: attractiveness, meaningfulness, and vitality (vividness).

The PI (29 items) construct was developed by Puto and Wells (1984). It consists of informational and transformational advertising content. Puto and Wells define an informational advertisement as one that provides consumers with factual, relevant brand data in a clear and logical manner such that the consumers have greater confidence in their ability to assess the merits of buying the brand after having viewed the advertisement. A transformational advertisement is one that associates the experience of using or consuming the advertised brand with a unique set of psychological characteristics that would not typically be associated with the brand experience to the same degree without exposure to the advertisement. Specifically, the advertisement itself links the brand to the capacity to provide the consumer with an experience that is different from the consumption experience that would normally be expected to occur without exposure to the commercial.

We consider the following path diagram to represent the structural model (Figure 1). This model based on theories reflects comprehensive and consistent relationships between television advertising and the advertising characteristics we are studying. 


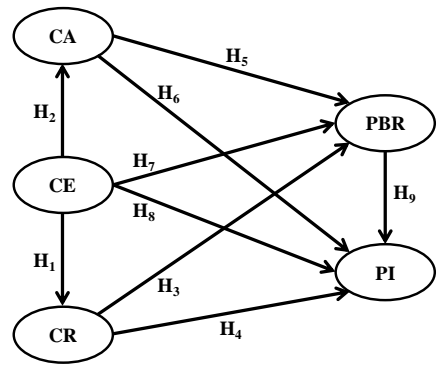

Figure 1: Path Diagram of the Structural Model and Hypotheses

\section{RESULTS}

\section{Data Collection}

A pre-test was performed on 30 people, and only minor changes were made based on the pre-test results. The survey was administered via an e-mail containing a link to the online questionnaire. Approximately 420 people were contacted, and 384 people responded (an overall response rate of 91.4\%). Out of 378 respondents, we deleted six responses from those who randomly responded to the questionnaire. The following analysis reflects a dataset of 378 responses. The respondents are described briefly below.

To address missing data, we used the complete case approach with list-wise deletion, as recommended for SEM with a sample size above 250 . To meet the assumption of multivariate normality, we examined the ratio of respondents to parameters. This ratio is equal to 4.61 (378 respondents to 82 parameters), which represents a limitation of our work. Nonetheless, we ensured that communalities were higher than .5; i.e., we used standardized loading estimates higher than .7 to assess convergence and model stability.

\section{The Sample Characteristics}

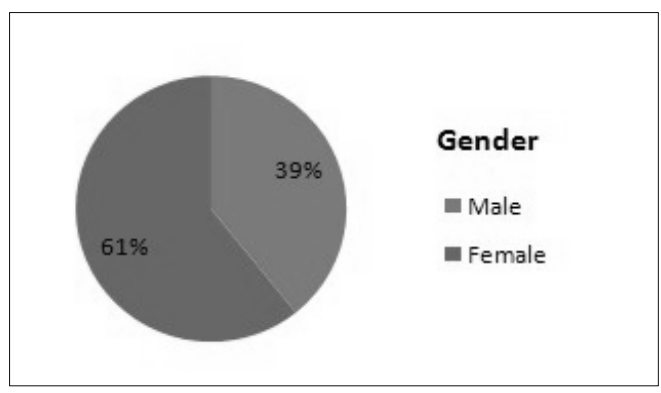

Figure 2: Gender of the Respondents

Figure 2 indicates that $61 \%$ of the respondents were women and $39 \%$ were men.

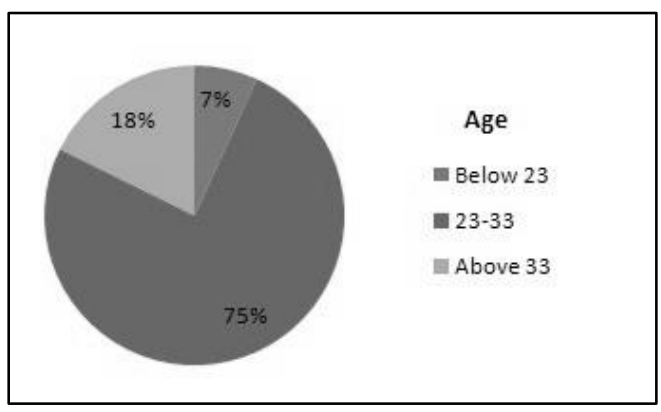

Figure 3: Age of the Respondents 
Figure 3 indicates that $75 \%$ of the respondents were between 23 and 33 years old, which was the targeted age group of the study.

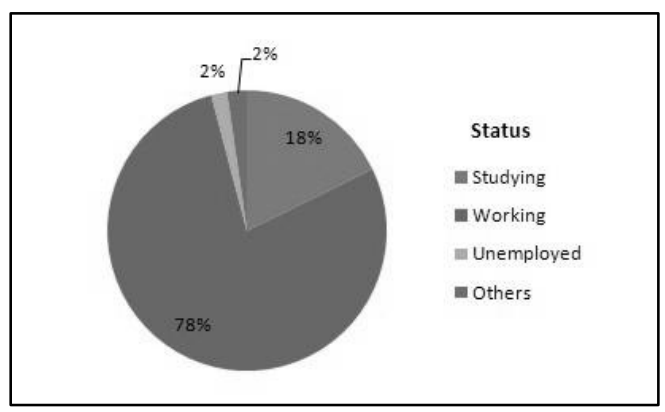

Figure 4: Employment Status of the Respondents

Figure 4 displays the employment status of the respondents. Most respondents were employed (78\%).

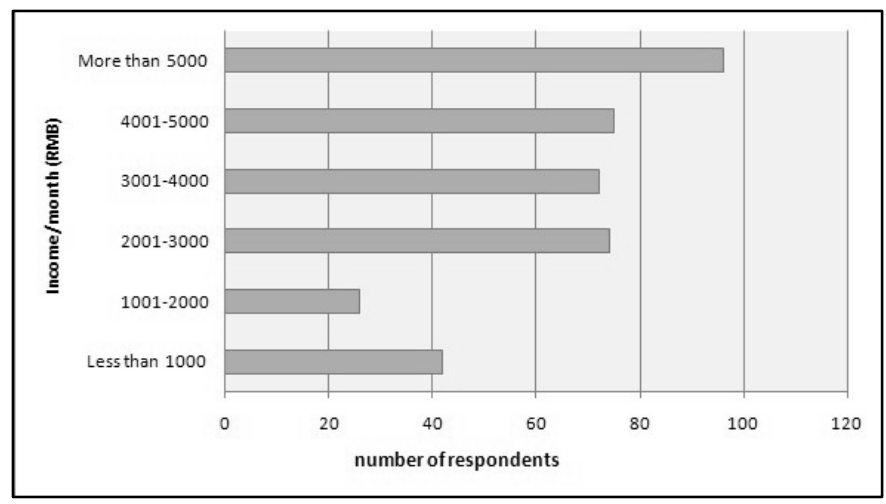

Figure 5: Income of the Respondents

Figure 5 indicates the respondents' monthly income. Because more than $50 \%$ of the respondents have an income above the average level, we can conclude that most of respondents have relatively high consumption level.

\section{Descriptive Statistics}

Table 1: Descriptive Statistics

\begin{tabular}{|l|c|c|c|c|c|c|}
\hline & Min & Max & Mean & Std. Dev & Skewness & Kurtosis \\
\hline CE_un_attractive & 1,0 & 7,0 & 3,307 & 1,2149 &, 519 &, 408 \\
\hline CE_no_classy & 1,0 & 7,0 & 3,376 & 1,1030 &, 384 &, 636 \\
\hline CE_un_beauti & 1,0 & 7,0 & 3,704 & 1,1526 &, 420 &, 404 \\
\hline CE_plain_no & 1,0 & 7,0 & 3,669 & 1,1373 &, 490 &, 684 \\
\hline CE_no_sexy & 1,0 & 7,0 & 3,429 & 1,1361 &, 183 &, 300 \\
\hline CE_un_dependable & 1,0 & 7,0 & 3,587 & 1,0823 &,- 031 &, 078 \\
\hline CE_no_honest & 1,0 & 7,0 & 3,862 & 1,0863 &, 026 &, 507 \\
\hline CE_un_reliable & 1,0 & 7,0 & 3,899 & 1,1379 &, 101 &, 127 \\
\hline CE_in_sincere & 1,0 & 7,0 & 3,918 & 1,1052 &, 139 &, 379 \\
\hline CE_un_trustworthy & 1,0 & 7,0 & 3,894 & 1,0971 &, 126 &, 388 \\
\hline CE_not_expert & 1,0 & 7,0 & 3,706 & 1,1704 &, 139 &, 155 \\
\hline CE_in_experienced & 1,0 & 7,0 & 3,728 & 1,1105 &, 286 &, 675 \\
\hline CE_un_knowledgeable & 1,0 & 7,0 & 3,791 & 1,1219 &, 317 &, 675 \\
\hline CE_un_qualified & 1,0 & 7,0 & 3,696 & 1,0779 &, 092 &, 840 \\
\hline CR_can_depend & 1,0 & 5,0 & 2,812 &, 9575 &, 347 &,- 141 \\
\hline CR_ad_is_for_inform & 1,0 & 5,0 & 2,458 &, 8858 &, 278 &,- 040 \\
\hline CR_ad_is_informative & 1,0 & 5,0 & 2,455 &, 8106 &, 371 &, 190 \\
\hline
\end{tabular}


Table 1 cont.

\begin{tabular}{|c|c|c|c|c|c|c|}
\hline CR_ad_truthful & 1,0 & 5,0 & 3,061 & ,8915 & ,084 &,- 101 \\
\hline CR_ad_reliable & 1,0 & 5,0 & 3,000 &, 8710 & ,097 &,- 224 \\
\hline CR_truth_told & 1,0 & 5,0 & 3,048 & ,8758 &, 026 &,- 125 \\
\hline CR_true_infos & 1,0 & 5,0 & 3,029 &, 8841 &, 105 &,- 208 \\
\hline CR_informed_after_ad & 1,0 & 5,0 & 2,847 & ,8226 &, 119 & ,101 \\
\hline CR_ad_enssential_infos & 1,0 & 5,0 & 2,765 & ,8432 & ,228 & ,276 \\
\hline CA_lot_fun & 1,0 & 6,0 & 3,426 & 1,0383 &, 120 &, 024 \\
\hline CA_seen_before & 1,0 & 6,0 & 2,889 & 1,2609 & ,235 &,- 539 \\
\hline CA_tired_of_it & 1,0 & 6,0 & 2,968 & 1,2008 &, 163 &,- 486 \\
\hline CA_clever_ad & 1,0 & 6,0 & 3,489 & 1,0434 &,- 056 &, 023 \\
\hline CA_fun_not_just_selling & 1,0 & 6,0 & 3,484 & 1,0635 &, 095 &,- 109 \\
\hline PBR_appealing & 1,0 & 2,0 & 1,233 & ,4232 & 1,270 &,- 390 \\
\hline PBR_probably_skip & 1,0 & 2,0 & 1,265 & ,4417 & 1,072 &,- 856 \\
\hline PBR_little_intrest & 1,0 & 2,0 & 1,413 &, 4930 &, 356 & $-1,883$ \\
\hline PBR_dislike & 1,0 & 2,0 & 1,685 &, 4651 &,- 801 & $-1,366$ \\
\hline PBR_ad_makes_me_feel_good & 1,0 & 2,0 & 1,362 &, 4813 &, 575 & $-1,679$ \\
\hline PBR_easily_forget & 1,0 & 2,0 & 1,484 & ,5004 &, 064 & $-2,007$ \\
\hline PBR_fascinate_ad & 1,0 & 2,0 & 1,484 &, 5004 &, 064 & $-2,007$ \\
\hline PBR_leave_me_cold & 1,0 & 2,0 & 1,532 & ,4997 &,- 128 & $-1,994$ \\
\hline PBR_beauti_ugly & 1,0 & 8,0 & 3,352 & 1,1144 & ,243 & 1,770 \\
\hline PBR_pleasant_un & 1,0 & 8,0 & 3,381 & 1,0939 &, 300 & 1,539 \\
\hline PBR_Gentle_harsh & 1,0 & 8,0 & 3,429 & 1,0736 & ,219 & 1,565 \\
\hline PBR_appealing_un & 1,0 & 8,0 & 3,548 & 1,1627 &, 189 & 1,051 \\
\hline PBR_attractive_un & 1,0 & 8,0 & 3,619 & 1,2069 &, 210 & 1,067 \\
\hline PBR_good_taste_no & 1,0 & 8,0 & 3,788 & 1,2178 &,- 094 & 593 \\
\hline PBR_exciting_un & 1,0 & 8,0 & 3,963 & 1,2839 &, 016 &, 553 \\
\hline PBR_intresting_un & 1,0 & 8,0 & 3,870 & 1,2643 & ,087 & ,754 \\
\hline PBR_worth_looking_no & 1,0 & 8,0 & 3,865 & 1,3010 &, 070 &, 470 \\
\hline PBR_comfort_no & 1,0 & 8,0 & 3,783 & 1,3072 &, 185 & ,566 \\
\hline PBR_coloerful_no & 1,0 & 8,0 & 3,847 & 1,3302 & ,223 &, 586 \\
\hline PBR_fascinate & 1,0 & 8,0 & 3,878 & 1,3054 &, 105 & ,426 \\
\hline PBR_meaningful & 1,0 & 8,0 & 3,807 & 1,2875 &, 147 & 415 \\
\hline PBR_convince & 1,0 & 8,0 & 3,876 & 1,3061 &, 146 & ,378 \\
\hline PBR_important_to_me & 1,0 & 8,0 & 4,079 & 1,3505 &, 134 &, 447 \\
\hline PBR_strong & 1,0 & 8,0 & 3,944 & 1,3007 & ,213 & ,755 \\
\hline PBR_honest & 1,0 & 8,0 & 3,765 & 1,2188 &, 079 & 610 \\
\hline PBR_easy_remember & 1,0 & 8,0 & 3,751 & 1,2559 &, 131 & ,305 \\
\hline PBR_easy_understand & 1,0 & 8,0 & 3,669 & 1,3208 & ,237 & ,234 \\
\hline PBR_worth_remember & 1,0 & 8,0 & 3,796 & 1,3043 &, 195 &, 400 \\
\hline PBR_simple & 1,0 & 8,0 & 3,603 & 1,2430 & ,213 &, 473 \\
\hline PBR_new & 1,0 & 8,0 & 3,786 & 1,3288 & ,324 & ,513 \\
\hline PBR_fresh & 1,0 & 8,0 & 3,746 & 1,2799 &, 339 & ,796 \\
\hline PBR_lively & 1,0 & 8,0 & 3,653 & 1,2882 &, 413 &, 783 \\
\hline PBR_sharp_washed_out & 1,0 & 8,0 & 3,767 & 1,2860 & ,231 & 605 \\
\hline PI_product_useful & 1,0 & 6,0 & 3,341 & ,9839 &, 314 &, 276 \\
\hline PI_think_there_in_the_ad & 1,0 & 6,0 & 3,275 & 1,0318 &, 114 &,- 081 \\
\hline PI_ad_is_meaningful & 1,0 & 6,0 & 3,328 & 1,0572 &, 045 &,- 350 \\
\hline PI_ad_not_fits_my_need & 1,0 & 6,0 & 3,307 & 1,0535 & ,264 &,- 031 \\
\hline PI_think_to_buy_or_not & 1,0 & 6,0 & 3,632 & 1,0972 &, 005 &,- 121 \\
\hline PI_ad_gives_good_idea & 1,0 & 6,0 & 3,505 & 1,0485 &, 055 &,- 119 \\
\hline PI_new_infos_of_ad & 1,0 & 6,0 & 3,108 & 1,0308 & ,205 &, 166 \\
\hline PI_want_expertise_in_ad & 1,0 & 6,0 & 3,241 & 1,0366 &, 252 & ,374 \\
\hline PI_not_clear & 1,0 & 6,0 & 3,413 & 1,0945 & ,359 &,- 176 \\
\hline PI_no_differ_from_others & 1,0 & 6,0 & 3,341 & ,9893 &, 116 &, 038 \\
\hline PI_brand_useful & 1,0 & 6,0 & 3,183 & 1,0228 & ,301 & 255 \\
\hline PI_ad_not_memorable & 1,0 & 6,0 & 3,228 & 1,0735 & ,093 &,- 193 \\
\hline
\end{tabular}


Table 1 cont.

\begin{tabular}{|l|c|c|c|c|c|c|}
\hline PI_ad_meaningful & 1,0 & 6,0 & 3,198 &, 9582 &, 431 &, 576 \\
\hline PI_ad_no_enough_infos & 1,0 & 6,0 & 3,249 &, 9616 &,- 012 &, 093 \\
\hline PI_ad_fits_my_life & 1,0 & 6,0 & 3,204 &, 9375 &, 263 &, 722 \\
\hline PI_ad_relates_to_me & 1,0 & 6,0 & 3,315 & 1,0086 &, 273 &, 312 \\
\hline PI_brand_is_good & 1,0 & 6,0 & 3,241 &, 9567 &, 397 &, 489 \\
\hline PI_company_provide_infos & 1,0 & 6,0 & 3,193 & 1,0389 &, 049 &,- 050 \\
\hline PI_brand_not_for_me & 1,0 & 6,0 & 3,317 & 1,0170 &, 260 &,- 005 \\
\hline PI_no_attention_to_ad & 1,0 & 6,0 & 3,122 & 1,0585 &, 227 &, 001 \\
\hline PI_ad_remind_product_facts & 1,0 & 6,0 & 2,852 &, 9548 &, 557 & 1,043 \\
\hline PI_hate_people_use_product & 1,0 & 6,0 & 3,571 & 1,1592 &, 108 &,- 312 \\
\hline PI_see_brand_think_this_ad & 1,0 & 6,0 & 3,116 & 1,0208 &, 156 &, 195 \\
\hline PI_think_right_there_in_the_ad & 1,0 & 6,0 & 3,320 & 1,0017 &, 327 &, 281 \\
\hline PI_compare_product_think_ad & 1,0 & 6,0 & 3,172 &, 9688 &, 371 &, 828 \\
\hline PI_ad_far_from_my_life & 1,0 & 6,0 & 3,437 & 1,0441 &, 092 &,- 079 \\
\hline PI_less_confidence_after_ad & 1,0 & 6,0 & 3,550 & 1,0499 &, 095 &,- 207 \\
\hline PI_memorable_ad & 1,0 & 6,0 & 3,397 & 1,0536 &, 342 &, 001 \\
\hline PI_good_feeling & 1,0 & 6,0 & 3,116 &, 8814 &, 378 &, 999 \\
\hline
\end{tabular}

Table 1 is presenting the descriptive statistics: the minimum, the maximum, the mean, the standard deviation, Skewness, and Kurtosis.

Tables 2, 3, 4, 5, and 6 are presenting the correlation matrices of the constructs: celebrity endorsement (CE), credibility of advertising (CR), creativity of advertising (CA), recall of product and brand (PBR), and purchasing intention (PI) respectively. The confidence levels are included in the following tables. $* *$ and $*$ indicates the significant at 0.01 and 0.05 respectively.

Table 2: The Correlation Matrix of Celebrity Endorsement (CE)

\begin{tabular}{|c|c|c|c|c|c|c|c|c|c|c|c|c|c|}
\hline & & & & & & & & & & & & & \\
\hline & 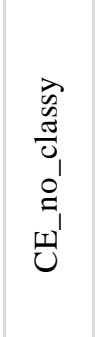 & 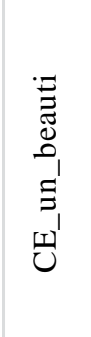 & 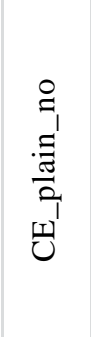 & $\begin{array}{l}\underset{x}{d} \\
\infty_{1} \\
0^{\prime} \\
\underbrace{}_{1} \\
\tilde{U}^{\prime}\end{array}$ & 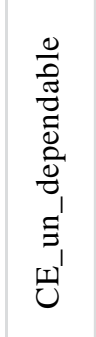 & 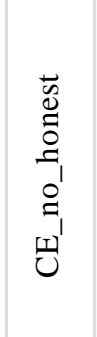 & 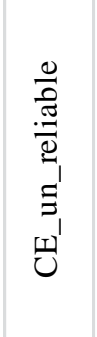 & 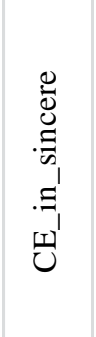 & 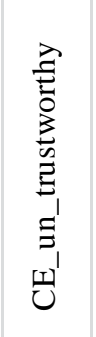 & 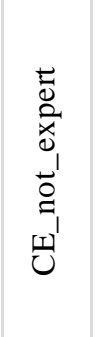 & 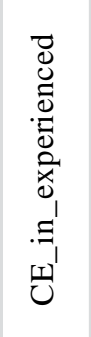 & 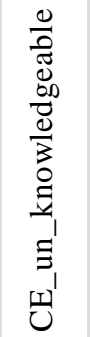 & 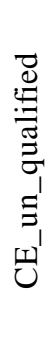 \\
\hline CE_no_classy & 1 & & & & & & & & & & & & \\
\hline CE_un_beauti &, $403^{* *}$ & 1 & & & & & & & & & & & \\
\hline CE_plain_no &, $230^{* *}$ &, $722^{* *}$ & 1 & & & & & & & & & & \\
\hline CE_no_sexy &, $115^{*}$ &, $401^{* *}$ &, $469^{* *}$ & 1 & & & & & & & & & \\
\hline CE_un_dependable &, $297^{* *}$ &, $280^{* *}$ &, $290^{* *}$ &, $453^{* *}$ & 1 & & & & & & & & \\
\hline CE_no_honest & ,074 &, $385^{* *}$ &, $416^{* *}$ &, $291^{* *}$ &, $362^{* *}$ & 1 & & & & & & & \\
\hline CE_un_reliable &, $123^{*}$ &, $438^{* *}$ &, $450^{* *}$ &, $239^{* *}$ &, $313^{* *}$ &, $733^{* *}$ & 1 & & & & & & \\
\hline CE_in_sincere & ,025 &, $347^{* *}$ &, $362^{* *}$ &, $216^{* *}$ &, $304^{* *}$ &, $673^{* *}$ &, $742^{* *}$ & 1 & & & & & \\
\hline CE_un_trustworthy & $129^{*}$ &, $437^{* *}$ &, $425^{* *}$ &, $130^{*}$ &, $182^{* *}$ &, $544^{* *}$ &, $669^{* *}$ &, $739^{* *}$ & 1 & & & & \\
\hline CE_not_expert &,- 038 &, $299^{* *}$ &, $393^{* *}$ &, $268^{* *}$ &, $180^{* *}$ &, $358^{* *}$ &, $422^{* *}$ &, $523^{* *}$ &, $662^{* *}$ & 1 & & & \\
\hline CE_in_experienced &, 004 &, $337^{* *}$ &, $380^{* *}$ &, $213^{* *}$ &, $118^{*}$ &, $365^{* *}$ &, $356^{* *}$ &, $392^{* *}$ &, $536^{* *}$ &, $644^{* *}$ & 1 & & \\
\hline CE_un_knowledgeable & ,087 &, $444^{* *}$ &, $470^{* *}$ &, $175^{* *}$ &, $136^{* *}$ &, $399^{* *}$ &, $449^{* *}$ &, $502^{* *}$ &, $514^{* *}$ &, $523^{* *}$ &, $710^{* *}$ & 1 & \\
\hline CE_un_qualified &, $268^{* *}$ &, $164^{* *}$ &, $173^{* *}$ &, $165^{* *}$ &, $360^{* *}$ &, $263^{* *}$ &, $224^{* * *}$ &, $264^{* * *}$ &, $186^{* * *}$ &, $137^{* *}$ &, $210^{* * *}$ &, $395^{* *}$ & 1 \\
\hline
\end{tabular}


Table 3: The Correlation Matrix of Credibility of Advertising (CR)

\begin{tabular}{|c|c|c|c|c|c|c|c|c|c|}
\hline & 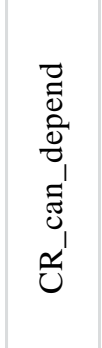 & 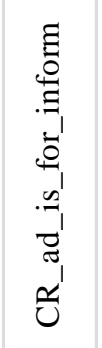 & 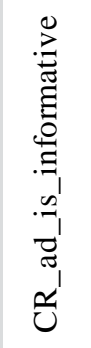 & 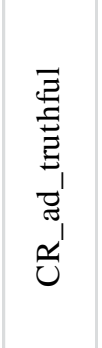 & 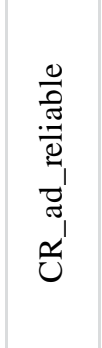 & 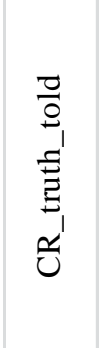 & 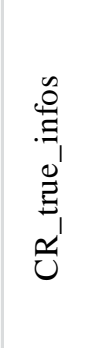 & 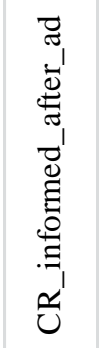 & 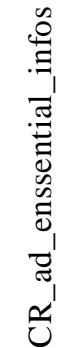 \\
\hline CR_can_depend & 1 & & & & & & & & \\
\hline CR_ad_is_for_inform &, $505^{* *}$ & 1 & & & & & & & \\
\hline CR_ad_is_informative &, $186^{* *}$ &, $492^{* *}$ & 1 & & & & & & \\
\hline CR_ad_truthful &, $520^{* *}$ &, $290^{* *}$ &, $292^{* *}$ & 1 & & & & & \\
\hline CR_ad_reliable &, $324^{* *}$ &, $306^{* *}$ &, $346^{* *}$ &, $618^{* *}$ & 1 & & & & \\
\hline CR_truth_told &, $362^{* *}$ & $266^{* *}$ &, $209^{* *}$ &, $543^{* *}$ &, $598^{* *}$ & 1 & & & \\
\hline CR_true_infos &, $345^{* *}$ & $274^{* *}$ &, $222^{* *}$ & $469^{* *}$ &, $558^{* *}$ &, $584^{* *}$ & 1 & & \\
\hline CR_informed_after_ad &, $388^{* *}$ &, $351^{* *}$ & $240^{* * *}$ &, $378^{* *}$ &, $385^{* *}$ &, $441^{* *}$ &, $495^{* *}$ & 1 & \\
\hline CR_ad_enssential_infos &, $425^{* *}$ &, $436^{* *}$ &, $320^{* *}$ &, $284^{* *}$ &, $303^{* *}$ &, $328^{* *}$ &, $383^{* *}$ &, $617^{* *}$ & 1 \\
\hline
\end{tabular}

Table 4: The Correlation Matrix of Creativity of Advertising (CA)

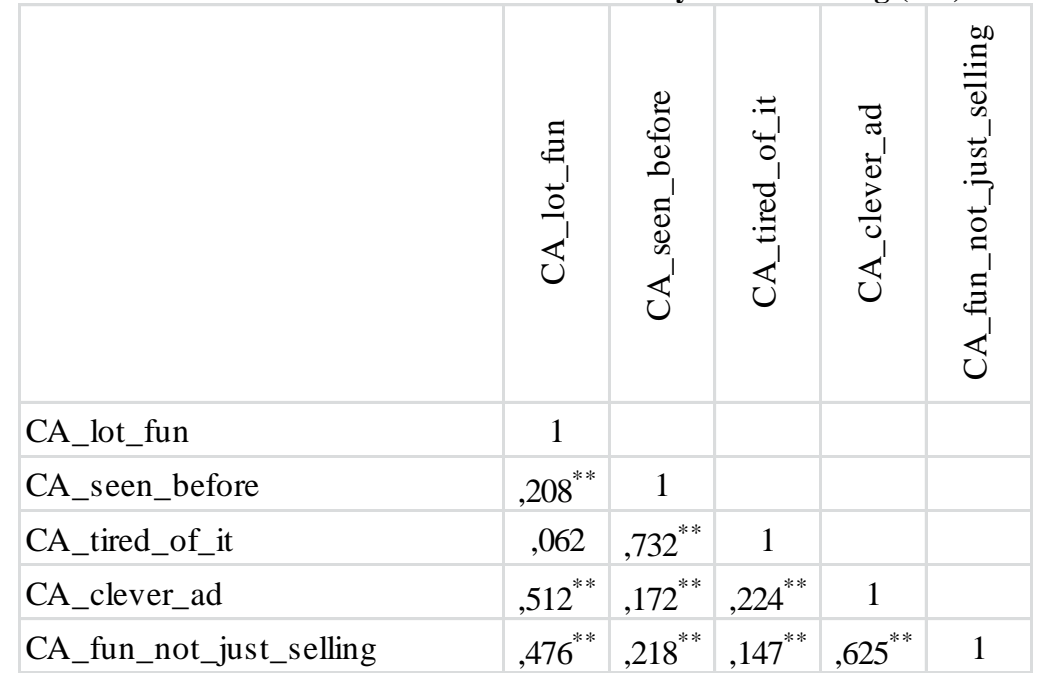




\section{Table 5: The Correlation Matrix of Recall of Product and Brand (PBR)}
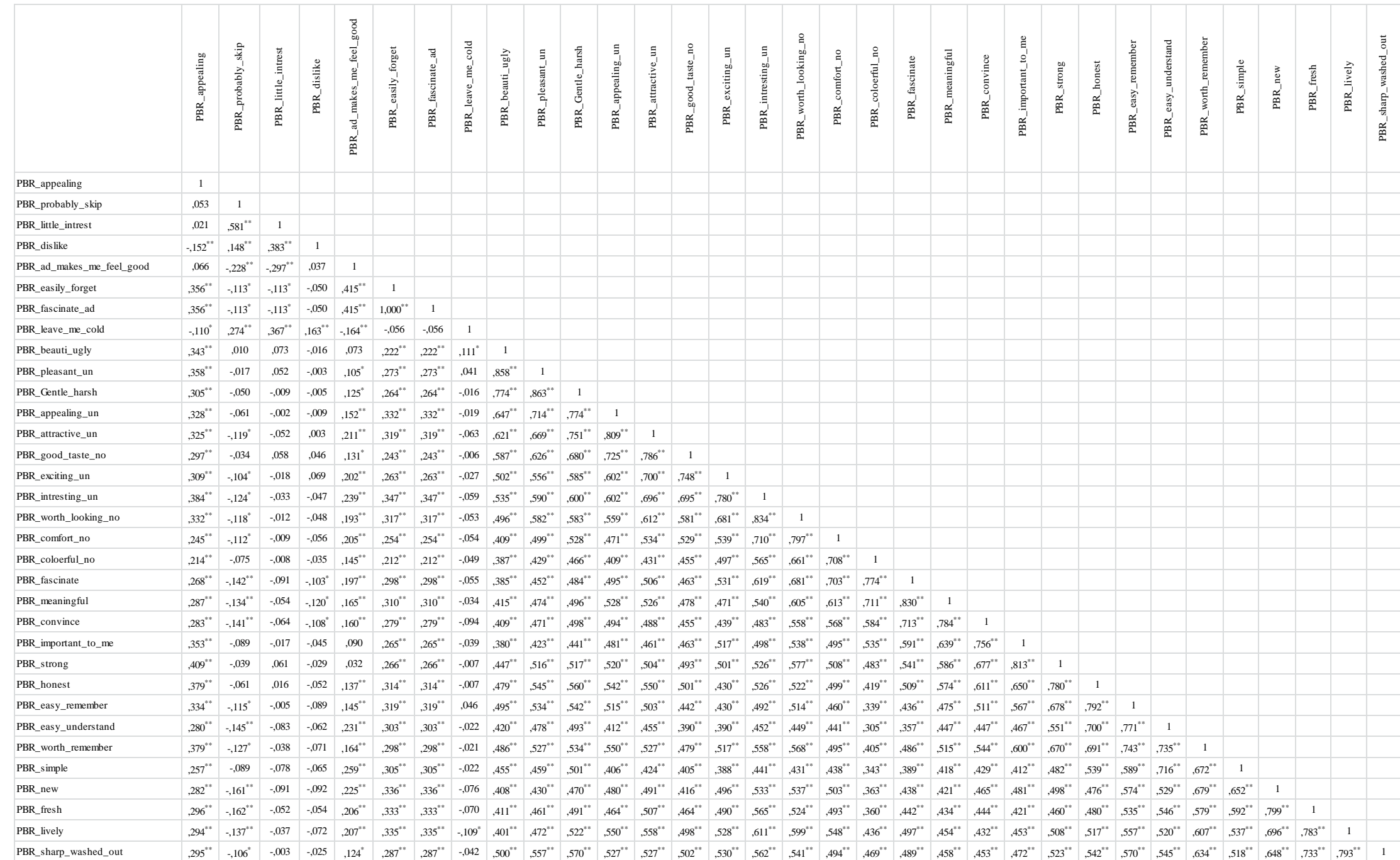
Table 6: The Correlation Matrix of Purchasing Intention (PI)

\begin{tabular}{|c|c|c|c|c|c|c|c|c|c|c|c|c|c|c|c|c|c|c|c|c|c|c|c|c|c|c|c|c|c|}
\hline & 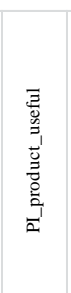 & 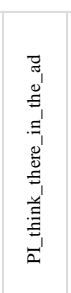 & 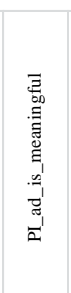 & 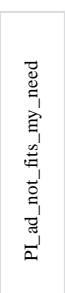 & 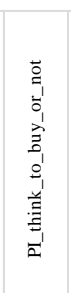 & 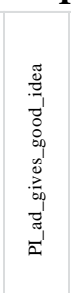 & 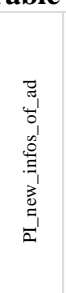 & 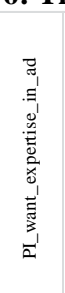 & 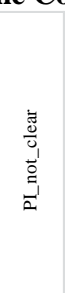 & 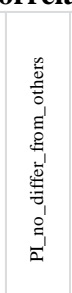 & 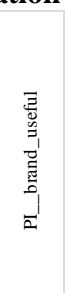 & 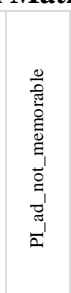 & 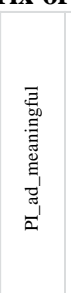 & 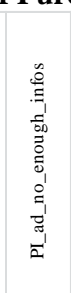 & 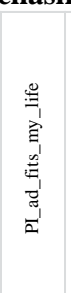 & 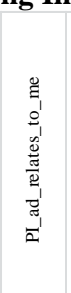 & 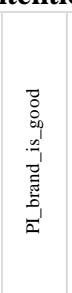 & 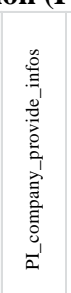 & 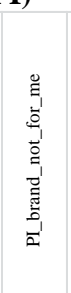 & 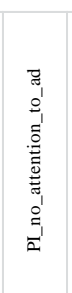 & 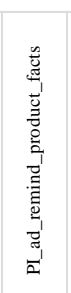 & 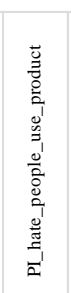 & 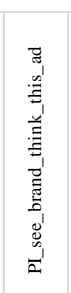 & 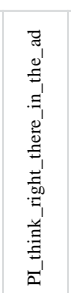 & 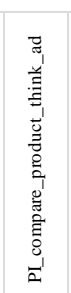 & 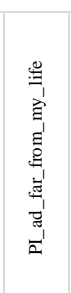 & 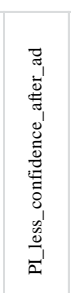 & 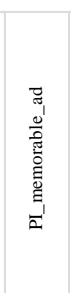 & 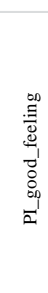 \\
\hline PI_product_useful & 1 & & & & & & & & & & & & & & & & & & & & & & & & & & & & \\
\hline PI_think_there_in_the_ad &, $610^{* *}$ & 1 & & & & & & & & & & & & & & & & & & & & & & & & & & & \\
\hline PI_ad_is_meaningful & $.578^{* *}$ &, $566^{* *}$ & 1 & & & & & & & & & & & & & & & & & & & & & & & & & & \\
\hline PI_ad_not_fits_my_need &,- 017 &, $144^{* *}$ &, $212^{* *}$ & 1 & & & & & & & & & & & & & & & & & & & & & & & & & \\
\hline PI_think_to_buy_or_not &, $458^{* *}$ &, $371^{* *}$ &, $479^{* *}$ &,- 010 & 1 & & & & & & & & & & & & & & & & & & & & & & & & \\
\hline PI_ad_gives_good_idea &, $429^{* *}$ &, $335^{* *}$ &, $487^{* *}$ &, 049 &, $660^{* *}$ & 1 & & & & & & & & & & & & & & & & & & & & & & & \\
\hline PI_new_infos_of_ad &, $112^{*}$ &, $196^{* *}$ &, 077 &, $192^{* *}$ &,- 028 &,- 070 & 1 & & & & & & & & & & & & & & & & & & & & & & \\
\hline PI_want_expertise_in_ad &, $148^{* *}$ &, $141^{* *}$ &, $141^{* *}$ &, $238^{* *}$ & ,029 &,- 010 &, $549^{* * *}$ & 1 & & & & & & & & & & & & & & & & & & & & & \\
\hline PI_not_clear &, $270^{* *}$ &, $181^{* *}$ &, $270^{* *}$ &, 044 &, $160^{* *}$ &, $241^{* *}$ &, $127^{*}$ & $207^{* * *}$ & 1 & & & & & & & & & & & & & & & & & & & & \\
\hline PI_no_differ_from_others &, $136^{* *}$ &, $178^{* *}$ &, $205^{* *}$ &, $123^{\circ}$ &, $150^{* *}$ &, $153^{* *}$ &, 052 &, $165^{* *}$ &, $568^{* *}$ & 1 & & & & & & & & & & & & & & & & & & & \\
\hline PI__brand_useful &,- 015 &,- 002 &, 035 &, $310^{* *}$ &,$- 179^{* *}$ &,$- 104^{*}$ &, $271^{* *}$ &, $389^{* * *}$ &, $286^{* *}$ &, $290^{* *}$ & 1 & & & & & & & & & & & & & & & & & & \\
\hline PI_ad_not_memorable &, 087 &, $111^{*}$ &, $137^{* *}$ &, 060 &, 069 &, $164^{* *}$ &, 042 &, $153^{* *}$ &, $423^{* *}$ &, $416^{* *}$ &, $349^{* *}$ & 1 & & & & & & & & & & & & & & & & & \\
\hline PI_ad_meaningful & ,055 & , 073 & ,051 & $244^{* *}$ &,- 092 &,- 100 &, $303^{* * *}$ &, $408^{* *}$ &, $238^{* *}$ &, $239^{* * *}$ &, $588^{* *}$ &, $273^{* * *}$ & 1 & & & & & & & & & & & & & & & & \\
\hline PI_ad_no_enough_infos &, $126^{*}$ &, $134^{* *}$ &, $196^{* *}$ & 008 &, $104^{*}$ &, $172^{* *}$ &, 029 &,- 010 &, $379^{* *}$ &, $393^{* *}$ &, $178^{* * *}$ &, $402^{* *}$ &, $280^{* *}$ & 1 & & & & & & & & & & & & & & & \\
\hline PI_ad_fits_my_life &,- 096 &,- 064 & ,037 &, $366^{* *}$ &,$- 131^{*}$ &,- 097 &, $147^{* *}$ & $263^{* *}$ &, $192^{* *}$ &, $188^{* *}$ &, $525^{* *}$ &, $212^{* * *}$ &, $531^{* *}$ &, $291^{* * *}$ & 1 & & & & & & & & & & & & & & \\
\hline PI_ad_relates_to_me &,- 082 &,- 053 &,- 005 &, $288^{* *}$ &,- 070 &,- 045 &, $115^{*}$ &, $232^{* * *}$ &, $127^{*}$ &, $150^{* *}$ &, $407^{* *}$ & ,081 &, $476^{* *}$ &, $225^{* * *}$ &, $639^{* *}$ & 1 & & & & & & & & & & & & & \\
\hline PI_brand_is_good &,$- 164^{* *}$ &,$- 140^{* * *}$ &,- 052 & $269^{* *}$ &,$- 150^{* *}$ &,$- 172^{* *}$ &, $172^{* * *}$ &, $273^{* *}$ &, $108^{*}$ &, $151^{* *}$ &, $421^{* *}$ & 089 &, $463^{* *}$ &, $111^{*}$ &, $625^{* *}$ & ,661" & 1 & & & & & & & & & & & & \\
\hline PI_company_provide_infos &, 094 &, $128^{*}$ &, $126^{*}$ &, $174^{* *}$ &,- 007 & ,086 &, $104^{*}$ &, $193^{* *}$ &, $219^{* *}$ &, $271^{* *}$ &, $244^{* * *}$ &, $284^{* * *}$ &, $292^{* *}$ &, $408^{* * *}$ &, $319^{* *}$ &, $256^{* *}$ &, $265^{* *}$ & 1 & & & & & & & & & & & \\
\hline PI_brand_not_for_me &, $180^{* *}$ &, $136^{* *}$ &, $115^{*}$ &, 033 &, $169^{* *}$ &, $202^{* *}$ &, 038 &, $108^{*}$ &, $320^{* *}$ &, $332^{* * *}$ &, $153^{* * *}$ &, $259^{* * *}$ &, $248^{* *}$ &, $364^{* *}$ &, $180^{* *}$ &, $195^{* *}$ &, $107^{*}$ &, $459^{* *}$ & 1 & & & & & & & & & & \\
\hline PI_no_attention_to_ad &, $217^{* * *}$ &, $249^{* *}$ &, $220^{* *}$ &,- 053 &, $272^{* *}$ &, $272^{* * *}$ & 007 &,- 017 &, $314^{* * *}$ &, $295^{* *}$ &,- 001 &, $358^{* *}$ &, 049 &, $434^{* * *}$ &, 028 &,- 048 &,$- 108^{*}$ &, $386^{* *}$ &, $501^{* *}$ & 1 & & & & & & & & & \\
\hline PI_ad_remind_product_facts &,- 084 &,- 029 &,- 025 &, $227^{* *}$ &,- 088 &,$- 105^{*}$ &, $256^{* *}$ &, $291^{* *}$ &,- 030 & ,017 &, $248^{* * *}$ & 054 &, $380^{* *}$ &, 072 &, $357^{* *}$ &, $418^{* * *}$ &, $425^{* *}$ &, $240^{* *}$ &, $155^{* *}$ &, $123^{*}$ & 1 & & & & & & & & \\
\hline PI_hate_people_use_product & $287^{7 *}$ &, $225^{* *}$ &, $122^{*}$ &,- 003 & $249^{* * *}$ & $205^{* * *}$ & ,003 & ,002 &, $309^{* *}$ &, $285^{* *}$ &,- 026 &, $217^{* * *}$ &, $125^{*}$ & $384^{* * *}$ &, 059 &, 066 &,- 014 &, $250^{* *}$ &, $372^{* *}$ & $.520^{* *}$ &, 093 & 1 & & & & & & & \\
\hline PI_see_brand_think_this_ad &,- 032 & ,027 &,- 011 & $258^{* * *}$ &,- 078 &,$- 112^{*}$ &, $225^{* *}$ & $204^{* *}$ &, 064 & ,076 &, $292^{* * *}$ &, $116^{*}$ &, $435^{* *}$ &, $170^{* * *}$ & $366^{* *}$ &, $392^{* *}$ & $381^{* *}$ &, $309^{* *}$ &, $113^{*}$ &, $119^{*}$ & $.557^{* *}$ & $260^{* *}$ & 1 & & & & & & \\
\hline PI_think_right_there_in_the_ad &,- 038 & ,022 &, 028 & $249^{* * *}$ &,- 054 &,- 016 &, $113^{*}$ &, $214^{* * *}$ &, $157^{* *}$ &, $197^{* *}$ &, $373^{* * *}$ &, $181^{* *}$ &, $492^{* *}$ &, $270^{* * *}$ &, $377^{* *}$ &, $470^{* *}$ &, $404^{* *}$ &, $228^{* *}$ &, $199^{* *}$ &, $133^{* *}$ &, $383^{* *}$ &, $249^{* * *}$ &, $591^{* *}$ & 1 & & & & & \\
\hline PI_compare_product_think_ad &,- 028 &, 024 &,- 016 &, $317^{* *}$ &,$- 130^{*}$ &,$- 164^{* *}$ &, $210^{* *}$ &, $228^{* *}$ &, 033 & ,088 &, $359^{* *}$ & ,097 &, $455^{* *}$ &, $111^{*}$ &, $452^{* *}$ & $468^{* *}$ &, $407^{* *}$ &, $252^{* *}$ &, 101 &,- 039 &, $406^{* *}$ &, $108^{*}$ &, $645^{* *}$ &, $610^{* *}$ & 1 & & & & \\
\hline PI_ad_far_from_my_life &, $123^{*}$ &, $152^{* *}$ &, $173^{* * 4}$ & 008 &, $175^{* *}$ &, $227^{* * 5}$ & -064 &, 045 &, $401^{* *}$ &, $392^{* *}$ &, 084 &, $458^{* *}$ &, $173^{* *}$ &, $417^{* * *}$ &, $199^{* *}$ &, $171^{* * *}$ & ,075 &, $299^{* *}$ &, $306^{* *}$ &, $396^{* *}$ & ,033 &, $486^{* *}$ &, $169^{* *}$ &, $312^{* *}$ &, $222^{* *}$ & 1 & & & \\
\hline PI_less_confidence_after_ad &, $218^{* *}$ &, $137^{* *}$ &, $207^{* *}$ & 099 &, $213^{* *}$ &, $224^{* * 8}$ &,- 045 & ,049 &, $370^{* *}$ &, $284^{* *}$ &, $116^{*}$ &, $324^{* *}$ &, $200^{* *}$ & $366^{* *}$ &, $204^{* *}$ &, $144^{* *}$ &, 034 &, $146^{* *}$ &, $320^{* *}$ &, $417^{* *}$ &, 010 &, $532^{* *}$ &, $131^{*}$ &, $316^{* *}$ &, $178^{* *}$ & $.576^{* *}$ & 1 & & \\
\hline PI_memorable_ad &,- 013 &,- 049 &,- 003 &, $194^{* *}$ &,$- 110^{*}$ &,$- 163^{* *}$ &, $114^{*}$ & $247^{* *}$ &, $212^{* * *}$ &, $180^{* *}$ &, $366^{* *}$ &, $230^{* * *}$ &, $500^{* *}$ & $214^{* * *}$ &, $423^{* *}$ &, $499^{* *}$ &, $437^{* *}$ &, $262^{* *}$ &, $229^{* *}$ & ,066 &, $349^{* *}$ &, $213^{* *}$ &, $487^{* *}$ &, $545^{* *}$ &, $479^{* *}$ &, $293^{* * *}$ &, $409^{* *}$ & 1 & \\
\hline PI_good_feeling &,- 067 &,- 015 &, 053 &, $376^{* *}$ &,$- 148^{* *}$ &,$- 118^{*}$ &, $188^{* *}$ &, $268^{* * *}$ &, 088 &, $119^{*}$ &, $335^{* *}$ &, $151^{* *}$ &, $371^{* *}$ &, $154^{* * *}$ &, $421^{* *}$ &, $436^{* *}$ & $366^{* *}$ &, $255^{* *}$ &, $157^{* *}$ &,- 027 &, $358^{* *}$ & ,072 &, $448^{* *}$ &, $444^{* *}$ &, $551^{* *}$ &, $250^{* *}$ &, $315^{* *}$ &, $581^{* *}$ & 1 \\
\hline
\end{tabular}




\section{Model}

To ensure that results are logical, it is important to consider issues of identification by ensuring that a model and problem estimation is clearly identified. Our model is over-identified (Kline, 2005), with 3,230 degrees of freedom (i.e., 3,403 distinct sample moments and 173 distinct parameters to be estimated). The analysis did not detect Heywood cases or illogical standardized parameters.

Reliability of the five constructs was examined using Cronbach's Alpha, which was greater than .70 for all factors (CE: .881, CR: .853, CA: .714, PBR: .967, and PI: .878). This result indicates acceptable consistency of the measurement items (Nunnally, 1978). Unidimensionality of each construct is addressed through principal component factor analysis with an orthogonal rotation (Hensley, 1999). Only one factor emerged, with all factor loadings above .80 and all variances extracted over $60 \%$ to assure the unidimensionality of instruments (Tu et al., 2004).

Construct validation also included tests for content, convergent, and discriminant validity. Content validity has been assessed by academic experts, the previous literature (Babbie, 2001), and reliability tests (Rust \& Cooil, 1994; Zwick, 1988). Our study only considered constructs that were well established in the literature. To assess the validity of the measurement model, we considered the root mean square error of the approximation (RMSEA), which is suitable for complex models and large sample sizes. The RMSEA should be below 0.10, and it was .094 for our model.

Bagozzi and Yi (1988) recommended using multiple fit indices, such as the Comparative Fit Index (CFI), Normed Fit Index (NFI), Incremental Fit Index (IFI), and x2/df ratio. Following Arbuckle and Wothke (1995), CFI, IFI, and NFI scores over 0.9 refer to a good model fit. Our model has a limited fit, with a CFI of .520, an IFI of .522, and a NFI of .456. The Tucker Lewis Index (TLI) as a non-normed index should approach one. Our analysis had a TLI of .507. We did not use modification to improve the overall fit of the model because we are in a confirmatory setting. Our objective is to test hypotheses without searching for improvements to the overall fit of the model.

\section{Research Results}

Table 7 is presenting the research results: paths, estimate, $p$ value, and the hypothesis.

Table 7: Research Results

\begin{tabular}{|l|c|c|c|}
\hline \multicolumn{1}{|c|}{ Path } & Estimate & P value & Hypothesis \\
\hline $\mathrm{CE} \rightarrow \mathrm{CR}$ & $-0,135$ & 0,013 & H1 is negatively supported \\
\hline $\mathrm{CE} \rightarrow \mathrm{CA}$ & 0,254 & 0,001 & H2 is supported \\
\hline $\mathrm{CR} \rightarrow \mathrm{PBR}$ & 0,543 & 0,001 & H3 is supported \\
\hline $\mathrm{CR} \rightarrow \mathrm{PI}$ & 0,024 & 0,64 & H4 is not supported \\
\hline $\mathrm{CA} \rightarrow \mathrm{PBR}$ & $-0,234$ & 0,001 & H5 is negatively supported \\
\hline $\mathrm{CA} \rightarrow \mathrm{PI}$ & 0,003 & 0,66 & H6 is not supported \\
\hline $\mathrm{CE} \rightarrow$ PBR & 0,017 & 0,79 & H7 is not supported \\
\hline $\mathrm{CE} \rightarrow$ PI & 0,004 & 0,647 & H8 is not supported \\
\hline PBR $\rightarrow$ PI & 0,005 & 0,644 & H9 is not supported \\
\hline
\end{tabular}

We did not use post hoc analysis to detect hypotheses that were not theorized prior to the data collection because we did not want to consider empirical evidence without a supporting theory. The total effect of CE on PBR is the sum of direct and indirect effects: $.254+(-.234)+(-.059)=-.039$

Summary of the research results:

- $\quad$ Celebrity endorsement is considered to be a creative method in television advertising (H2).

- $\quad$ This study demonstrates that the credibility of television advertising is an important element in determining whether consumers recall the advertised product and brand (H3). 
- $\quad$ Celebrities in television advertising or people who have professional knowledge as endorsers decrease the credibility of television advertisements contrary to the results of previous research (H1).

- Creativity in television advertising negatively affects product and brand recall, contrary to the results of previous research $(\mathrm{H} 5)$.

\section{DISCUSSION AND CONCLUSION}

\section{Support of the Initial Assumptions}

This paper is based on a survey of perceptions and attitudes toward television advertising in the Chinese market. The targets are the young generation in China, most of whom have Internet access. This study reveals the effects of several elements in television advertising, including creativity of advertising (CA), celebrity endorsement (CE), credibility of advertising (CR), recall of product and brand (PBR), and purchasing intention (PI).

The results of this study indicate that a significant relationship exists between celebrity endorsement and advertising creativity. Consumers believe that commercials with celebrities are more creative than those without celebrities. In other words, the use of celebrities signifies that an advertisement is creative. Thus, "H2: CE has a positive effect on CA" is supported.

According to Heath and Stipp (2011) and Rubinson (2009), television advertising is still a useful tool for persuading consumers. It effectively generates brand awareness. Consumers still believe what advertisements say, and they are persuaded by television advertisements. We found that the credibility of television advertisements will cause consumers to recall the advertised brand and product. Thus, "H3: CR has a positive effect on PBR" is supported.

\section{Deviations from What was Expected}

Based on previous studies, marketers always choose attractive, credible celebrities in television advertising or people who have professional knowledge as endorsers because these positive images can persuade consumers. Consumers will believe that the products and brands endorsed are as the endorsers claim in the advertisement, and thus, consumers will purchase the advertised products (Hakimi et al., 2011). However, our results demonstrate a significant and negative relationship exists between endorsers and the credibility of television advertisements. Therefore, "H1: CE has a positive effect on CR" is not supported in our study. This study demonstrates that CE has a negative effect on $\mathrm{CR}$ which is a counter intuitive finding.

Based on many previous studies, creative advertisements can attract the attention of consumers. Creative advertisements are more impressive for consumers and encourage them to recall advertised products and brands (Ang et al., 2007). Jones (1990) finds that creative advertisements can help consumers remember the advertisement. Till and Baack (2005) demonstrate that creative advertisements will remain in consumers' memories for a longer period of time than 'normal' commercials, and consumers recall the advertisements much easier, even after a period of time. Previous research also indicates that creativity in advertising will satisfy consumers emotionally (Kover et al., 1995). According to previous studies, a significant relationship exists between creativity in television advertising and consumers' recall of advertised products and brands. However, we find that creativity has a negative effect on product and brand recall. Consumers recall the advertised product and brand less frequently if the advertisement was more creative. Therefore, "H5: CA has a positive effect on PBR" is not supported. This study demonstrates that CA has a negative effect on PBR.

\section{Relation of the Findings to Earlier Work}

Heath and Stipp (2011) conclude that television advertising can build a stronger brand and persuade consumers. However, the results of our study demonstrate that advertising credibility is not directly related to purchase intention. Credible advertising does not make consumers buy the product and brand. Therefore, "H4: CR has a positive effect on PI" is not supported by our study. 
Previous studies have found that creativity in television advertising can generate emotional responses among consumers, which is a critical element to persuade and influence consumer attitudes toward brands, purchase intention, and likability (Besser \& Lewis, 2000). Ang and Low (2000), Kover et al. (1995), and Stone et al. (2000) demonstrate that creative advertising improves consumers' attitude toward the brand, purchase intention, and likability. Plummer (2006) also finds that creative advertisements can lead to positive attitudes toward the brand and purchase intentions. Unfortunately, our study did not find evidence to support a relationship between creativity and purchase intention. Therefore, "H6: CA has a positive effect on PI" is not supported.

To enhance the value of advertised brands and products, marketers always choose a celebrity who matches the brand image to create congruity between the product and endorser (Chien et al., 2011). This congruity will arouse the recall of product and brand when consumers see or think about the endorsers. Attractive celebrities are used to impress viewers when they watch the television advertisement. The aim is also to make consumers to recall the product and brand endorsed when they choose among several similar products. However, our study found no evidence of a positive relationship between celebrity endorsement and consumers' recall of products and brands. Therefore, "H7: CE has a positive effect on PBR" is not supported by this study.

Concerning the relationship between celebrity endorsement and purchase intention, Ohanian (1990) confirms that a credible celebrity can persuade consumers and that their message in television advertising can convince consumers to buy the advertised products. Lafferty and Goldsmith (1999) find that younger consumers prefer to use products endorsed by celebrities. Celebrities affect how young people choose and switch brands, according to Martin and Bush (2000). Our study found no significant relationship between celebrity endorsement and purchase intention. Therefore, our results do not support "H8: CE has a positive effect on PI."

We believe that consumers' recall of products and brands affects purchase intention via several elements of advertising, including celebrity endorsement and creativity. However, we did not find a significant relationship between product and brand recall and purchase intention in this study. Therefore, "H9: PBR has a positive effect on PI" is not supported.

\section{Theoretical Implications}

From a theoretical perspective, our study supported two relationships well described in the literature. Celebrity endorsement carry creativity in television advertising and the credibility of television advertising determine whether consumers recall the advertised product and brand. However, we argue that two relationships between celebrity endorsement and credibility of the advertisement and between the creativity of television advertising and product and brand recall are significant but negatively related, as opposed to the existing studies in the field.

\section{Practical Implications}

Those findings have practical implications. It is worth discussing whether advertisers and marketers neglect their main objective of promoting products and brands when they pursue creative advertisements. When consumers finish watching the advertisement, how many of them only remember a wonderful advertisement rather than the product and brand advertised? This study also did not observe a relationship between purchase intention and any other advertising elements. Advertising credibility, celebrity endorsement, creativity, and the recall of products and brands do not alter consumers' intentions to purchase. This paper reveals the general market features of China's young generation, which is valuable information for international companies entering the Chinese market. It encourages practitioners to adapt the advertisement to the targeted country and must measure the impact of the advertisement.

\section{Limitations and Further Research}

One limitation of this study is that the targeted population (respondents) was not specifically and precisely selected, meaning that consumers came from various cities. Within countries, consumers' attitudes and perceptions are based on regions, socioeconomic categories, subcultures, and consumption levels. In China, the living standards and economic levels, which affect consumption, vary significantly from one city to another. 
Concerning the current effectiveness of television advertising, more researchers are discussing the relationship between television advertising and the Internet. Some studies claim that the Internet creates a synergy with television to enhance the effectiveness of advertising (Briggs \& Stipp, 2000). According to our study, 54.3\% of Chinese respondents spend more than five hours using a computer or smartphone, and $83.4 \%$ spend more than three hours online. Therefore, the effect of the Internet on advertising in the Chinese market is worth considering in future research.

\section{AUTHOR INFORMATION}

Lijie Li is a graduate student at the ESC Rennes School of Business in France. E-mail: lijie.li@esc-rennes.fr

Laurent Scaringella is an assistant professor at the ESC Rennes School of Business in France and a visiting scholar at the Haas School of Business at the University of California, Berkeley. E-mail: laurent.scaringella@esc-rennes.fr (Corresponding author)

\section{REFERENCES}

1. Anderson, J. R. (1983). A spreading activation theory of memory. Journal of Verbal Learning and Verbal Behavior, 22, 261-95.

2. Ang, S. H., \& Low, S. Y. M. (2000). Exploring the dimensions of ad creativity. Psychology and Marketing, 17(10), 835-54.

3. Ang, H. S., Lee, Y. H., \& Leong, S. M. (2007). The ad creativity cube: Conceptualization and initial validation. Journal of the Academy of Marketing Science, 35, 220-32.

4. Arbuckle, J. L., \& Wothke, W. (1995). Amos 4.0 user's guide. Chicago: Small Waters Corporation.

5. Arora, R. (2005). China's 'Gen Y' bucks tradition: Youngest Chinese reject Confucian work ethic, embrace west. Washington, DC: Gallup Poll News Service.

6. $\quad$ Aziz, S., Ghani, U., \& Niazi, A. (2013). Impact of celebrity credibility on advertising effectiveness. Pakistan Journal of Commerce and Social Sciences, 7(1), 107-127.

7. Babbie, E. (2001). Practice of social research (9th ed.). Belmont, CA: Wadsworth Thomson Learning.

8. Bagozzi, R., \& Yi, Y. (1988). On the evaluation of structural equation models. Journal of the Academy of Marketing Science, 16(1), 74-94.

9. Baker, M. J., \& Churchill G. A. Jr. (1977). The impact of physically attractive models on advertising evaluations. Journal of Marketing Research, 14(4), 538-55.

10. Barme, G. R. (1999). In the red: On contemporary Chinese culture. New York: Columbia University Press.

11. Bemman, S., Schweda, A., \& Varan, D. (2010). The residual impact of avoided television advertising. Journal of Advertising, 39(1), 67-81.

12. Bentler, P. M. (1988). Causal modeling via structural equation systems. In J. R. Nesselroade \& R. B. Cattell (eds.), Handbook of multivariate experimental psychology. New York: Plenum.

13. Bornstein, R. F. (1989). Exposure and affect: Overview and meta- analysis of research. 1968-1987. Psychological Bulletin, 106, 265-89.

14. Bransford, J. D., \& Johnson, M. K. (1972). Consideration of some problems of comprehension. In W. G. Chase (ed.), Visual information processing. New York: Academic.

15. Briggs, R., \& Stipp, H. (2000). How Internet advertising works. In Excellence in International Research. Amsterdam: ESOMAR.

16. Buksa, I., \& Mitsis, A. (2011). Generation Y's athlete role model perceptions on PWOM behavior. Young Consumers: Insight and Ideas for Responsible Marketers 12(4), 337-47.

17. Callow, M., \& Schiffman, L. G. (2004). Sociocultural meanings in visually standardized print ads. European Journal of Marketing, 38(9/10), 1113-28.

18. Caughey, J. L. (1984). Imaginary social worlds: A cultural approach. Lincoln, NE: University of Nebraska Press.

19. Caughey, J. L. (1985). Mind games: Imaginary social relationships in American sport. In G. A. Fine (ed.). Meaningful play, playful meaning. Champaign. IL: Human Kinetics Publishers.

20. Caughey, J. L. (1994). Gina as Steven: The social and cultural dimensions of a media relationship. Visual Anthropology, 10, 126-35. 
21. Chaiken, S. (1979). Communicator physical attractiveness and persuasion. Journal of Personality and Social Psychology, 37(2), 1387-97.

22. Chan, K. (2008). Use of celebrity in television commercials of youth products. (Working paper). Hong Kong: Hong Kong Baptist University.

23. Chien, P. M., Cornwell, T. B., \& Pappu, R. (2011). Sponsorship portfolio as a brand-image creation strategy. Journal of Business Research, 64(2), 142-9.

24. Croll, E. (2006). China's new consumers: Social development and domestic demand. London: Routledge.

25. Davis, S. D. (2000). Introduction: A revolution in consumption. In D. S. Davis (ed.). The consumer revolution in urban China. Berkeley, CA: University of California Press.

26. Dix, S., Phau, I., \& Pougnet, S. (2010). Bend it like Beckham: The influence of sports celebrities on young adult consumers. Young Consumers: Insight and Ideas for Responsible Marketers, 11(1), 36-46.

27. Erdogan, B., \& Baker, M. (2000). Celebrity endorsement: Advertising agency managers' perspective. The Cyber Journal of Sport Marketing, 13, 1-15.

28. Fam, K. S., Waller, D. S., \& Erdogan, Z. (2004). The influence of religion on the attitudes towards the advertising of controversial products. European Journal of Marketing, 38(5/6), 537-55.

29. Fam, K. S., Waller, D. S., De Run, E. C., \& He, J. (2013). Advertising dislikeability in Asia. Is there a relationship with purchase intention and frequency? Asia Pacific Journal of Marketing and Logistics, 25(1), 144-161.

30. Fay, M. (2004). Cyclical patterns in the content of advertisements: Replication, confirmation, extension and revision. European Journal of Marketing, 40(1/2), 198-217.

31. Fraser, B. P., \& Brown, W. J. (2002). Media, celebrities, and social influence: Identification with Elvis Presley. Mass Communication and Society, 5(2), 183-206.

32. Gilmore, R. F., \& Secunda, E. (1993). Zipped TV commercials boost prior learning. Journal of Advertising Research, 33(6), 28-38.

33. Greene, W. F. (1988). Maybe the valley of the shadow isn't so dark after all. Journal of Advertising Research, 28, 11-5.

34. Gu, F. F., Hung, K., \& Tse, D. K. (2008). When does guanxi matter: Issues of capitalization and its dark sides. Journal of Marketing, 72(4), 12-28.

35. Haberland, G. S., \& Dacin, P. A. (1992). The development of a measure to assess viewers judgments of the creativity of an advertisement: A preliminary study. Advances in Consumer Research, 19, 817-25.

36. Hakimi, B. Y., Abedniya, A., \& Zaeim, M. N. (2011). Investigate the impact of celebrity endorsement on brand images. European Journal of Scientific Research, 58(1), 116-32.

37. Health, R. G., \& Stipp, H. (2011). The secret of television's success: Emotional content or rational information? - After fifty years the debate continues. Journal of Advertising Research, 51(1), 112-23.

38. Heckler, S. E., \& Childers, T. L. (1992). The role of expectancy and relevancy in memory for verbal and visual information: What is incongruency? Journal of Consumer Research, 18(4), 475-92.

39. Hensley, R. L. (1999). A review of operations management studies using scale development techniques. Journal of Operations Management, 17(3), 343-58.

40. Hsu, C. K., \& Mcdonald, D. (2002). An examination on multiple celebrity endorsers in advertising. Journal of Product \& Brand Management, 11(1), 19-29.

41. Hughes, C. R. (2006). Chinese nationalism in the global era. New York: Routledge.

42. Jones, J. P. (1990). Advertising: Strong force or weak force? Two views an ocean apart. International Journal of Advertising, 9(3), 233-46.

43. Joreskog, K. G. (1993). Testing structural equation models. In K. A. Bollen \& J. S. Lang (eds.). Testing structural equation models. Newbury Park, CA: Sage.

44. Joseph, W. B. (1982). The credibility of physically attractive communicators: A review. Journal of Advertising. 11(3), 15-24.

45. Kahle, L. R., \& Homer, P. M. (1985). Physical attractiveness of the celebrity endorser: A Social adaption perspective. Journal of Consumer Research, 11(4), 954-61.

46. Kalra, A., \& Goodstein, R. C. (1998). The impact of advertising positioning strategies on consumer price sensitivity. Journal of Marketing Research, 35(2), 210-24.

47. Kamins, A., Brand, M. J., Hoeke, S. A., \& Moe, J. C. (1989). Two-sided versus one-sided celebrity endorsements: The impact on advertising effectiveness and credibility. Journal of Advertising, 18(2), 4-10. 
48. Kamins, M. A., \& Gupta, K. (1994). Congruence between spokesperson and product type: A match-up hypothesis perspective. Psychology and Marketing, 11(6), 569-86.

49. Keller, K. L. (1993). Conceptualizing, measuring, and managing customer-based brand equity. Journal of Marketing, 57(I), 1-22.

50. Kilburn, D. (1998). Star power. Adweek (Eastern Edition), 39(2), 20-1.

51. Kline, R. B. (2005). Principles and practice of structural equation modeling. New York: Guilford.

52. Kover, A. J., Goldberg, S. M., \& William, L. J. (1995). Creativity vs. effectiveness? An integrating classification for advertising. Journal of Advertising Research, 35(6), 29-39.

53. Lafferty, B. A., \& Goldsmith, R. E. (1999). Corporate Creditability's role in consumers' attitudes and purchase intentions when a high versus a low creditability endorser is used in the ad. Journal of Business Research, 4(2), 109-16.

54. Lastovicka, J. L. (1983). Convergent and discriminant validity of television commercial rating scales. Journal of Advertising, 12(2), 14-23.

55. Lears, J. J. (1994). Fables of abundance: A cultural history of advertising in America. New York: Basic Books.

56. Lee, Y. W., \& Mason, C. (1999). Responses to information incongruency in advertising: The role of expectancy, relevancy, and humor. Journal of Consumer Research, 26(2), 156-69.

57. Makgosa, R. (2010). The influence of vicarious role models on purchase intentions of Botswana teenagers. Young Consumers: Insight and Ideas for Responsible Marketers, 11(4), 307-19.

58. Marchand, R. (1985). Advertising the American dream: Making way for modernity, 1920-1940. Berkeley, CA: University of California Press.

59. Martin, C. A., \& Bush, A. J. (2000). Do role Models influence teenagers' purchase intentions and behavior? Journal of Consumer Marketing, 17(5), 441-54.

60. McCracken, G. (1989). Who is the celebrity endorser? Cultural foundations of the endorsement process. Journal of Consumer Research, 16(3), 310-21.

61. McGruire, W. J. (1985). Attitudes and attitude change. In G. Lindzey \& E. Aronson (eds.). Handbook of social psychology (Vol. 2). New York: Random House.

62. Mills, J., \& Aronson. E. (1965). Opinion change as a function of communicator's attractiveness and desire to influence. Journal of Personality and Social Psychology, 1(2), 173-7.

63. Misra, S., \& Beatty, S. E. (1990). Celebrity spokesperson and brand congruity. Journal of Business Research, 21(2), 159-73.

64. Mohammad, E. A., \& Seyyed, Y. E. J. (2011). An investigation of TV advertisement effects on customers' purchasing and their satisfaction. International Journal of Marketing Studies, 3(4), 175-81.

65. Mediamark Research \& Intelligence. (2008). In a multitasking world, much media consumption occurs individually. Retrieved from http://www.mediamark.com/PDF/MRIPR_091608_Media Multitasking.pdf

66. Nordheilm, C. L. (2002). The influence of level of processing on advertising repetition effects. Journal of Consumer Research, 29(3), 371-82.

67. Nunnally, J. (1978). Psychometric theory. New York: McGraw-Hill.

68. Obermiller, C., \& Spangenberd, E. (1998). Development of a scale to measure skepticism toward advertising. Journal of Consumer Psychology, 7(2), 159-86.

69. Ohanian, R. (1990). Construction and validation of a scale to measure celebrity endorsers, perceived expertise, trustworthiness, and attractiveness. Journal of Advertising, 19, 39-52.

70. Ohanian, R. (1991). The impact of celebrity spokesperson's perceived image on consumers' intention to purchase. Journal of Advertising Research, 31(1), 46-52.

71. Papper, R., Holmes, M., Popovich, M., \& Bloxham, M. (2005). Middletown media studies. 1 \& 2: Media day and concurrent media exposure. Muncie, IN: Ball State University Publications.

72. Plummer, J. T. (2006). Editorial: What do people do with advertising? The critical question. Journal of Advertising Research, 46(1), 1.

73. Puto, C. P., \& Wells, W. D. (1984). Informational and transformational advertising: The differential effects of time. In T. C. Kinnear (ed.), Advances in consumer research (Vol. 11). Provo, UT: Association for Consumer Research.

74. Ramalingam, V., Palaniappan, B., Panchnatham, N., \& Palanivel, S. (2006). Measuring advertising effectiveness - a neural network approach. Journal of Business Research, 31(1), 159-60.

75. Ray, M. L. (1982). Advertising and communication management. Englewood Cliffs, NJ: Prentice Hall. 
76. Rice, R. E., \& Atkin, C. K. (2001). Public communication campaigns (3rd ed.). Thousand Oaks, CA: Sage.

77. Rubinson, J. (2009). Empirical evidence of TV advertising effectiveness. Journal of Advertising Research.

78. Rust, R. T., \& Cooil, B. (1994). Reliability measures for qualitative data: Theory and implications. Journal of Marketing Research, 31(1), 1-14.

79. Sengupta, J., Goodstein, R. C., \& Boninger, D. S. (1997). All cues are not created equal: Obtaining attitude persistence under low-involvement conditions. Journal of Consumer Research, 23(4), 351-61.

80. Srull, T. K. (1981). Person memory: Some tests of associative storage and retrieval models. Journal of Experimental Psychology, Human Learning and Memory, 1(6), 440-46.

81. Stanat, M. (2006). China's generation y: Understanding the future leaders of the world's next superpower. Paramus, NJ: Homa \& Sekey.

82. Stone, G., Besser, D., \& Lewis, L. E. (2000). Recall, liking, and creativity in TV commercials: A new approach. Journal of Advertising Research, 40(3), 7-18.

83. Teixeira, T. S., \& Stipp, H. (2013). Optimizing the amount of entertainment in advertising. Journal of Advertising Research, 53(3), 286-296.

84. Till, B. D., \& Busler, M. (1998). Matching products with endorsers: Attractiveness versus expertise. Journal of Consumer Marketing, 15(6), 576-86.

85. Till, B. D., \& Baack, D. W. (2005). Recall and persuasion - Does creative advertising matter? Journal of Advertising, 34(3), 47-57.

86. Tom, G., Clark, R., Elmer, L., Grech, E., Masetti, J. J., \& Sandhar, H. (1992). The use of created versus celebrity spokespersons in advertising. Journal of Consumer Marketing, 9(4), 45-51.

87. Tu, Q., Vonderembse, M. A., Ragu-Nathan, T. S., \& Ragu-Nathan, B. (2004). Measuring modularity-based manufacturing practices and their impact on mass customization capability: A customer-driven perspective. Decision Sciences, 35(2), 147-68.

88. Wang, J. (2008). Brand new China: Advertising, media, and commercial culture. Cambridge, MA: Harvard University Press.

89. Weber, I. G. (2000). Challenges facing China's Television advertising industry in the age of spiritual civilization: An industry analysis. International Journal of Advertising, 19, 259-81.

90. Wells, W. D. (1964). EQ, son of EQ, and the reaction profile. Journal of Marketing, 28, 45-52.

91. Widgery, R. N., \& Ruch, R. S. (1981). Beauty and the machiavellian. Communication Quarterly, 29(4), 297-301.

92. Williamson, J. (1978). Decoding advertisements: Ideology and meaning in advertising. London, Marion Boyars.

93. Woltman Elpers, J. L. C. M., Wedel, M., \& Pieters, R. G. M. (2003). Why do consumers stop watching TV commercials? Two experiments on the influence of moment-to-moment entertainment and information value. Journal of Marketing Research, 40, 437-453.

94. Xu, G. Q. (2008). Olympic dreams: China and sports. Cambridge, MA: Harvard University Press.

95. Yang, X., \& Smith, R. E. (2009). Beyond attention effects: Modeling the persuasive and emotional effects of advertising creativity. Marketing Science, 28, 935-949.

96. Yoo, B., \& Donthu, N. (2001). Developing and validating a multidimensional consumer-based brand equity scale. Journal of Business Research, 52(1), 1-14.

97. Zufryden, F. S., James H. P., \& Sankaralingam. (1993). A zapping and its impact on brand purchase behavior. Journal of Advertising Research, 33(1), 58-66.

98. Zwick, R. (1988). Another look at interrater agreement. Psychological Bulletin, 103(3), 374. 